\title{
Nomenclature of the Bacterial Leaf Streak Pathogen of Rice
}

\author{
J. F. BRADBURY \\ Commonwealth Mycological Institute, Kew, Surrey, England
}

\begin{abstract}
The name Xanthomonas translucens f. sp. oryzae was originally proposed for the organism that causes leaf blight of rice, but it has recently been used for the leaf streak organism, and confusion has resulted. It is proposed that the leaf streak organism be called Xanthomonas translucens $\mathrm{f}$. $\mathrm{sp}$. oryzicola, a name that is nomenclaturally more acceptable.
\end{abstract}

For many years it was thought that the only bacterial disease of rice plants was bacterial leaf blight, caused by Xanthomonas oryzae (Uyeda and Ishiyama 1928) Dowson 1939. Bacterial leaf streak was first distinguished from blight by Fang et al. (3), who showed that it is caused by a different pathogen that they named Xanthomonas oryzicola.

In 1958, Pordesimo published his studies of a bacterial disease of rice in the Philippines (6). He showed that the causal organism was very closely related to Xanthomonas translucens (Jones, Johnson, and Reddy 1917) Dowson 1939 , and, thinking that he was working with leaf blight, proposed the name Xanthomonas translucens (Jones, Johnson, and Reddy) Dowson f. sp. oryzae. He was apparently unaware of the work of Fang et al. (3).

Goto (4) pointed out that Pordesimo's illustrations show the symptoms of bacterial streak, not blight, and that his results confirm that he was working with $X$. oryzicola rather than $X$. oryzae. Goto's own results confirm that the two pathogens are distinct and that $X$. oryzicola can justifiably be considered a forma specialis of $X$. translucens. He therefore suggested that the name $X$. translucens f. sp. oryzae be used for the streak pathogen, and this use has been gaining acceptance by plant pathologists. However, the name was proposed by Pordesimo for the leaf blight organism, and its derivation is clearly from the specific epithet oryzae given to the blight organism by Uyeda and Ishiyama (7). The name is therefore misleading, and its use has already caused the two organisms to be confused.
The wide acceptance of Goto's suggestion shows that there is a need to indicate the relationship of the rice bacterial streak organism with the other cereal streak bacteria already grouped as formae speciales of $X$. translucens. It is therefore proposed that the streak organism be named Xanthomonas translucens (Jones, Johnson, and Reddy) Dowson $\mathrm{f}$. sp. oryzicola. The basionym is Xanthomonas oryzicola Fang et al. 1957 (see reference 3, p. 119).

\section{LITERATURE CITED}

1. Dowson, W. J. 1939. On the systematic position and generic names of the gram negative bacterial plant pathogens. Zentralbl. Bakteriol. Parasitenk. Abt. 2 100:177-193.

2. Dowson, W. J. 1943. On the generic names Pseudomonas, Xanthomonas and Bacterium for certain bacterial plant pathogens. Trans. Brit. Mycol. Soc. 26:1-14.

3. Fang, C. T., H. C. Ren, T. Y. Chen, Y. K. Chu, H. C. Faan, and S. C. Wu. 1957. A comparison of the rice bacterial leaf blight organism with the bacterial leaf streak organism of rice and Leersia hexandra Swartz. Acta Phytopathol. Sinica 3:99-124 (in Chinese; English summary).

4. Goto, M. 1964. Nomenclature of the bacteria causing bacterial leaf streak and bacterial stripe of rice. Bull. Fac. Agr. Shizuoka Univ. 14:3-10.

5. Jones, L. R., A. G. Johnson, and C. S. Reddy. 1917. Bacterial blight of barley. J. Agr. Res. 11:625-644.

6. Pordesimo, A. N. 1958. Bacterial blight of rice. Philipp. Agr. 42:115-128.

7. Uyeda and Ishiyama. 1928. In S. Ishiyama (ed.), Bacterial leaf-blight of the rice plant. Proc. Third Pan-Pacific Sci. Congr. Tokyo, Oct.-Nov. 1926 2:2112. 